\title{
ORIENTASI NILAI BUDAYA BATAK TOBA, ANGKOLA DAN MANDAILING DALAM MEMBINA INTERAKSI DAN SOLIDARITAS SOSIAL ANTAR UMAT BERAGAMA DI TAPANULI UTARA (ANALISIS SOSIOLOGIS)
}

\author{
Harisan Boni Firmando \\ Institut Agama Kristen Negeri (IAKN) Tarutung \\ boni.harisan@iakntarutung.ac.id
}

\begin{abstract}
Abstrak
Masyarakat yang beragam sangat perlu dirawat keharmonisannya agar tidak menimbulkan kecurigaan, perbedaan pandangan yang mengarah pada kesalahpahaman, pertentangan dan berujung pada konflik. Sistem Kemasyarakatan Dalihan na tolu yang diorientasikan dalam nilai budaya masyarakat Batak Toba, Angkola dan Mandailing menjadi modal utama dalam membina interaksi dan solidaritas sosial antar umat beragama. Terjadinya silang budaya melalui adaptasi, akulturasi dan asimilasi antara masyarakat lokal dan pendatang menjadi cara dalam membina interaksi dan solidaritas social antar umat beragama di Tapanuli Utara. Metode yang digunakan dalam penelitian adalah metode deskriptif dengan pendekatan kualitatif. Data dikumpulkan dengan observasi dan wawancara. Unit analisis dan informasi adalah masyarakat lokal dan pedatang. Data ditafsirkan menggunakan catatan lapangan.
\end{abstract}

Kata Kunci : Nilai Budaya, Interaksi, Solidaritas Sosial

\begin{abstract}
Diverse society really needs to be maintained harmony so as not to arouse suspicion, differences in views that lead to misunderstanding, conflict and lead to conflict. The Dalihan na tolu Community System which is oriented in the cultural values of the Batak. Toba, Angkola and Mandailing communities is the main capital in fostering interaction and social solidarity between religious communities. The occurrence of cross culture through adaptation, acculturation and assimilation between local people and migrants is a way to foster interaction and social solidarity between religious communities in North Tapanuli. The method used in this research is descriptive method with a qualitative approach. Data collected by observation and interview. The unit of analysis and information is the local and migrant communities. Data are interpreted using field notes.
\end{abstract}

Keywords : Cultural Values, Interaction, Social Solidarity 


\section{Pendahuluan}

Dunia modern membawa masyarakat berkembang dengan sangat pesat serta membawa mobilitas yang sangat tinggi yang menimbulkan Desa dunia, sehingga tidak ada lagi batas-batas dalam berbagai hal. Menyikapi perkembangan yang begitu pesat, masyarakat harus siap menghadapi situasi-situasi terbaru, termasuk kebaharuan dalam konteks keberagaman. Indonesia merupakan negara majemuk yang terdiri dari beragam suku, agama dan budaya.

Interaksi sosial dalam masyarakat harus terjalin dengan baik guna menjaga keharmonisan antarpribadi maupun kelompok. Salah satu potensi yang sangat bernilai dalam masyarakat adalah nilai budaya. Beragam nilai budaya yang dimiliki menjadi kekayaan dan sumber kekuatan bagi bangsa untuk melangkah maju bersama serta membina kerukunan masyarakat. Sumber kekuatan yang berasal dari kearifan lokal wajib dilestarikan agar kekuatannya semakin bertambah dari waktu ke waktu. Pertambahan kekuatan tersebut dilakukan seiring dengan masuknya unsur kebudayaan asing dari suku atau etnis yang satu kepada suku atau etnis yang lain. Masuknya unsur kebudayaan tersebut dilakukan setiap individu yang berbeda latar belakang melalui proses sosial, yang terjadi setelah individu tersebut saling bergaul secara intensif, sehingga berdampak pada percampuran sifat khas unsur-unsur kebudayaan tersebut. Keragaman juga dapat menimbulkan perbedaan yang sangat mencolok antar pribadi, kelompok dan etnis, oleh sebab itu setiap individu, kelompok, etnis diharapkan mampu beradaptasi agar tidak mengalami kejutan kebudayaan (culture shock) yang dimulai dari perbedaan pandangan, mengarah pada kesalahpahaman, pertentangan dan berujung pada konflik.

Dalam kehidupan sehari-hari manusia selalu berhubungan dengan yang lain, setiap individu mempunyai perannya masing-masing, bergerak dan mempengaruhi lingkungan di sekitarnya begitu juga sebaliknya alam sekitar juga mempengaruhi individu, baik tingkah laku, perbuatan, pikiran, sikap, perasaan, kemauan, dan lain sebagainya. Hubungan semacam ini disebut sebagai autoplastis yaitu seseorang harus menyesuaikan dirinya dengan lingkunganya dan alloplastis yaitu seseorang dapat pula mengubah lingkungannya agar sesuai dengan keinginan dirinya (Ahmadi, 2007: 49).

Kabupaten Tapanuli Utara berada dalam Provinsi Sumatera Utara memiliki jumlah penduduk sebesar 299.881 jiwa yang tersebar di 15 Kecamatan (BPS 
Kabupaten Tapanuli Utara 2018: 1). Hasil sensus tahun 2010, sebanyak 90,23\% dari 279.257 penduduk Tapanuli Utara adalah pemeluk Kristen, 4,76\% Islam, 4,58\% Katolik, 0,05\% Budha, 0,002\% Kong Hu Cu, 0,001\% Hindu, 0,009\% agama lainnya, dan 0,35\% tidak terjawab atau tidak menyatakan sebagai agama tersebut (BPS 2010). Secara keseluruhan Kabupaten Tapanuli Utara didominasi oleh suku Batak Toba, ada pula sebagian kecil yang merupakan suku terdekat Batak Toba, yakni Batak Simalungun, Batak Karo, Batak Angkola dan Batak Pakpak. Ada pula sebagian kecil orang Jawa, Minangkabau dan Tionghoa, yang banyak terdapat di Tarutung dan Siborongborong (www.taputkab.go.id).

Dari penjabaran di atas penulis memfokuskan pembahasan tentang interaksi dan solidaritas sosial antar umat beragama pada masyarakat Batak Toba, Angkola dan Mandailing di Kabupaten Tapanuli Utara, yang memiliki nilai kepercayaan nenek moyang dan hidup dalam perbedaan agama, bahkan perbedaan tersebut dapat ditemukan dalam satu keluarga. Interaksi sosial yang terjadi diantara masyarakat Batak Toba, Angkola dan Mandailing terjalin sangat kuat, dikarenakan adanya kesamaan marga serta adanya sistem kekerabatan dalihan na tolu yang semakin mempererat interaksi sosial antar umat beragama.

Teori solidaritas sosial digunakan dalam penelitian ini sebagaimana yang dikemukan oleh Emile Durkheim dalam bukunya "The Division Of Labour in Society", menurut durkheim solidaritas sosial ialah kesetiakawanan yang menunjuk pada satu keadaan hubungan antara individu dan atau kelompok yang didasarkan pada perasaan moral dan kepercayaan yang dianut dan diperkuat oleh pengalaman emosional bersama (Jones, 2009: 123). Durkheim membahas tentang suatu gejala yang terdapat dalam masyarakat dalam persoalan pembagian kerja, istilah yang digunakan ialah integrasi sosial (social integration) dan kekompakan sosial (social integration). Durkheim mengembangkan teori solidaritas dan meletakkannya sebagai teori sentral dalam dunia sosiologi.

Dengan menggunakan perspektif Durkheim maka akan diketahui bagaimana perasaan moral dan kepercayaan yang dianut etnis Batak Toba, Angkola dan Mandailing melalui sistem kemasyarakatan daliban na tolu dan diperkuat pengalaman emosional bersama yang diwujudkan dalam nilai budaya, serta bagaimana masyarakat berinteraksi sehingga tercipta solidaritas antar etnik dan kerukunan antar umat beragama di era modern saat ini. 


\section{Metode Penelitian}

Metode yang dipergunakan dalam studi ini adalah metode kualitatif, untuk memahami fenomena tentang apa yang dialami oleh subjek penelitian secara holistik, dengan cara mendeskripsikan dengan kata-kata dan bahasa, pada suatu konteks khusus yang alamiah dan dengan memanfaatkan berbagai metode alamiah. Kriteria individu menjadi informan kunci adalah tokoh adat dan tokoh agama yang merupakan pengurus dalam perkumpulan sosial seperti perkumpulan Serikat Tolong Menolong (STM), marga, pengurus Masjid dan Gereja. Sedangkan informan pelaku ditentukan bersamaan dengan perkembangan review dan analisis hasil penelitian saat penelitian berlangsung yaitu keluarga, pengurus STM, Mesjid, Gereja dan generasi muda yang langsung merasakan hidup sebagai anggota masyarakat. Pada studi ini ada 20 orang informan yang diwawancarai. Studi ini dilakukan di empat Kecamatan yaitu Kecamatan Siborong-borong, Kecamatan Sipoholon, Kecamatan Tarutung dan Kecamatan Siatas Barita. Pemilihan empat Kecamatan tersebut dikarenakan masyarakat di daerah tersebut telah beragam dalam etnis, agama dan mata pencaharian, serta sudah saling beradaptasi, berakulturasi dan berasimilasi dalam kehidupan kesehariannya.

\section{Sistem Kemasyarakatan Dalihan Na Tolu dalam masyarakat Batak Toba, Angkola dan Mandailing}

Pada hubungan yang lebih khusus sistem kemasyarakatan disebut sistem kekerabatan. Sistem kekerabatan memegang peranan penting dalam jalinan hubungan baik antara individu dengan individu atau individu dengan masyarakat lingkungannya. Di dalam sistem kekerabatan terdapat pula, kelompok kekerabatan, sistem keturunan, sistem istilah kekerabatan dan sopan santun pergaulan kekerabatan. Pada kelompok yang bersangkutan ada harga dan rasa kepribadian yang didasari para anggotanya, ada hak dan kewajiban yang turut mengatur interaksi mereka, disamping pimpinan yang mengorganisir kegiatan kelompok (Gultom, 1992: 59).

Sistem kekerabatan mempunyai arti penting dalam banyak masyarakat baik masyarakat sederhana maupun masyarakat yang sudah maju, hubungan dengan nenek moyang dan kerabat adalah kunci hubungan dalam struktur sosial. Hubungan dengan kerabat tersebut menjadi poros dari berbagai interaksi, kewajiban-kewajiban, loyalitas, 
dan sentimen-sentimen. Dalam masyarakat loyalitas kekerabatan sangat penting pada kerabat menggantikan loyalitas pada yang lain. Artinya sistem kekerabatan sangat erat kaitannya dengan struktur sosial yang dibangunnya lebih lanjut. Sistem kekerabatan menentukan posisi seseorang dalam masyarakat, yaitu posisi laki-laki dan posisi perempuan (Meiyenti, 2012: 57).

Daliban na tolu adalah nilai budaya, gagasan prima dari penciptanya yang menjadi sumber atau orientasi dari sikap dan tingkah laku suku Batak di dalam kehidupannya pada hubungan bersosial budaya. Dalam hubungan sosial budaya tersebut dalihan na tolu adalah sistem kemasyarakatan suku Batak atau dalam hubungan lebih khusus disebut sistem kekerabatan (Gultom, 1992: 60). Segala kegiatan masyarakat Batak dalam hubungan sosial budaya baru dikatakan sempurna apabila telah didukung ketiga kelompok kekerabatan dongan sabutuba atau dongan tubu, bula-bula dan boru, ibarat daliban (tungku) yang mendukung periuk, belanga tempat memasak nasi, lauk-pauk dan minuman. Yang dimasak atau diciptakan oleh dongan sabutuba, bula-bula dan boru ini adalah budaya untuk turunan-turunan mereka ibarat nasi, lauk-pauk dan minuman merupakan bekal bagi kelanjutan hidup para turunannya (Gultom, 1992: 61).

Dikatakan dongan sabutuba karena lahir dari rahim (butuba) yang sama yaitu ibu mereka sendiri. Dalam perkembangan selanjutnya yang termasuk kelompok kekerabatan dongan sabutuha ini adalah saudara-saudara laki-laki seayah, saudarasaudara laki-laki senenek, saudara-saudara laki-laki senenek moyang, saudara-saudara laki-laki semarga berdasarkan sistem keturunan kekeluargaan garis laki-laki atau patrilineal.

Orang tua dari pihak isteri atau mertua dinamai hula-bula. Dalam hubungan yang lebih luas, keluarga bula-bula, kelompok kekerabatan pihak bula-bula, saudara laki-laki semarga dari bula-bula berdasarkan sistem kekeluargaan prinsip patrilineal, keseluruhannya menjadi bula-bula. Dalam hubungan lebih lanjut bahwa semua saudara perempuan disebut dengan boru atau kelompok penerima isteri.

Kehidupan masyarakat Angkola dan Mandailing juga ditata oleh sistem dalihan na tolu, yaitu hubungan tiga unsur kekerabatan; kahanggi (teman semarga), anak boru (kelompok pengambil istri) dan mora (pihak pemberi istri). Daliban na tolu dijadikan pedoman berkomunikasi (berbahasa dan tutur), bertindak dan menyelesaikan masalah sosial. Dalam keyakinan keberagamaan dalihan na tolu menjadi 
norma kehidupan. Dalam kehidupan sehari-hari terjadi interaksi saling ketergantungan antara adat dan agama baik disadari maupun tidak. Dalihan na tolu menjadi panutan dalam kehidupan sehari-hari. Dalihan na tolu akan lebih terlihat upacara (horja), baik dalam upacara suka (siriaon) dan duka (silulutan).

Selain ketiga elemen yang telah dijelaskan di atas (Hula-bula, Dongan Sabutuba dan Boru). Dalihan na tolu juga mempunyai satu elemen "pembantu". Dasar berpikirnya adalah adakalanya dalihan tidak sempurna, tidak sesuai dengan ukuran alat masak, karena itulah diperlukan batu kecil untuk menopang dalihan. Batu kecil itulah yang dinamakan sibal-sibal (Gultom, 1992 : 52). Adapun yang termasuk kelompok sihal-sihal adalah sahabat, kenalan, teman sekampung, marga lain, dan bahkan suku bangsa lain yang tidak termasuk dalam ketiga golongan fungsional Daliban na tolu. Hal ini senada dengan pepatah Batak yang berkata: "Jonok partubu, jonokan parbudul", artinya dekat hubungan berkerabat adalah lebih dekat hubungan bertetangga. Selain tetangga, sahabat juga sangat berarti dalam kehidupan masyarakat Toba. Hal itu tampak dalam peribahasa berikut: "Sirang marale-ale lobian matean ina", artinya berpisah dengan teman akrab/sahabat (ale-ale), rasanya seperti kematian ibu (Sinaga, 2006: 1520).

Paradigma Clifford Geertz memandang budaya (Dalihan na tolu) sebagai sebuah teks yang perlu dibaca sehingga dapat menemukan perilaku masyarakat Batak Toba. Dalihan na tolu menjadi tiang penyangga dan penjamin kehidupan yang harmonis bagi seluruh tatanan kebudayaan Batak Toba. Sistem Dalihan na tolu bersifat liquid dan terbuka. Karena itu memungkinkan untuk dimasuki oleh setiap orang. Setiap orang Batak Toba pasti akan pernah menempati ketiga posisi dalam Dalihan na tolu, sebagai Hula-bula, Dongan Sabutuba atau Boru (Simanjuntak, 2002: 358). Penentuan posisi itu tergantung pada kegiatan apa yang dibuat pada saat itu dan siapa yang menjadi pelaksana kegiatan. Dalam hal ini marga berfungsi menentukan kedudukan dan hubungan kekerabatan antara seseorang dengan pelaksana kegiatan (sipemilik acara) (Gultom, 1992: 53).

Falsafah Dalihan na tolu mengedepankan kesetaraan, kesederajatan, sama pentingnya satu sama lain. Tidak ada yang lebih tinggi dan lebih rendah, semuanya sama. Tidak ada diskriminasi, tidak pembedaan baik atas agama, ras, atau golongan. Penulis menemukan ada keutamaan penting tersembul di sini, yaitu "adil". Disebut 
adil karena kehidupan dan keluhuran martabat setiap manusia dibela dan dimuliakan (Riyanto, 2013 : 79-81).

\section{Nilai Budaya sebagai modal utama dalam membina Solidaritas Sosial}

Nilai budaya Batak Toba, Angkola dan Mandiling menjadi modal utama dalam membina solidaritas sosial antar umat beragama. Adapun nilai budaya yang mencakup segala aspek kehidupan masyarakat Batak Toba, Angkola dan Mandailing dikelompokkan dalam Sembilan nilai, yang selanjutnya disebut nilai budaya utama. Kesembilan nilai budaya utama itu ialah: Kekerabatan, Religi, Hagabeon, Hasangapon, Hamoraon, Hamajuon, Hukum, Penganyoman dan Konflik (Harahap \& Siahaan, 1987 : 133-134).

Solidaritas sosial merupakan tema utama yang dibicarakan oleh Durkheim sebagai sumber moral untuk membentuk tatanan sosial di tengah masyarakat. Durkheim menyatakan bahwa asal usul otoritas moralitas harus ditelusuri sampai pada sesuatu yang agak samar-samar yang disebut "masyarakat". Durkheim membagi solidaritas sosial kepada dua kelompok, yaitu solidaritas mekanik dan organik. Durkheim menggunakan istilah solidaritas mekanik dan organik untuk mengalisa masyarakat keseluruhan, bukan hanya organisasi-organisasi dalam masyarakat (Soekanto, 1985: 4-9).

\section{Solidaritas Mekanik dalam Nilai Budaya Batak Toba, Angkola dan Mandailing}

Konsep solidaritas sosial merupakan konsep sentral Emille Durkheim dalam mengembangkan teori sosiologi. Durkheim menyatakan bahwa solidaritas sosial merupakan suatu keadaan hubungan antara individu dan atau kelompok yang didasarkan pada perasaan moral dan kepercayaan yang dianut bersama dan diperkuat oleh pengalaman emosional bersama (Johnson, 1964: 174).

Orang Batak mengajarkan kepada anak-anak, bahwa solidaritas bukan hanya dalam suasana duka, tetapi juga dalam suasana gembira. Ini mengandung makna mendidik, bertanggung jawab seperti diungkapkan dalam pesan tradisional ; Marboras ma dangkana, Marmutik ma ranting na, Horas-horas ma hahana, Songoni ma nang angina, yang berarti Berbuahlah cabangnya, Berputiklah rantingnya, Selamat- 
selamatlah abangnya, Demikian juga adiknya. Diajarkan untuk senantiasa bersedia menjadi teman bersuka sekaligus teman membagi duka. Solidaritas semacam ini sangat kuat pada orang Toba (Harahap \& Siahaan, 1987 : 146).

Pandangan Durkheim mengenai masyarakat adalah sesuatu yang hidup, masyarakat berpikir dan bertingkah laku dihadapkan kepada gejala-gejala sosial atau fakta-fakta sosial yang seolah-olah berada di luar individu. Fakta sosial yang berada di luar individu memiliki kekuatan untuk memaksa. Pada awalnya, fakta sosial berasal dari pikiran atau tingkah laku individu, namun terdapat pula pikiran dan tingkah laku yang sama dari individu-individu yang lain, sehingga menjadi tingkah laku dan pikiran masyarakat, yang pada akhirnya menjadi fakta sosial. Fakta sosial yang merupakan gejala umum ini sifatnya kolektif, disebabkan oleh sesuatu yang dipaksakan pada tiaptiap individu (Johnson, 1964: 183).

\section{$>$ Hubungan Kekerabatan}

Kekerabatan mencakup hubungan primordial suku, kasih sayang atas dasar hubungan darah, kerukunan, unsur-unsur Daliban na tolu (Mora/Hulabula, Kahangi/Dongan Sabutuba, Anak Boru/Boru), Pisang Raut (anak boru dari anak boru), Hatobangon (cendikiawan) dan segala yang berkaitan dengan hubungan kekerabatan karena pernikahan, solidaritas marga dan lain-lain. Sosialisasi Dalihan na tolu yang mencakup marga, silsilah dan tutur, merupakan pendidikan dasar primordial suku yang kuat. Masyarakat Toba, Angkola dan Mandiling sangat mahir dalam memaparkan hubungan kekerabatan yang dikaitkan dengan silsilah marga. Hubungan kekerabatan berdasarkan Dalihan na tolu mengajarkan solidaritas dan penghargaan kepada orang lain. Tidak ada orang yang hanya duduk dalam posisi bula-bula, subut atau boru saja, namun berganti-ganti sesuai dengan situasi dan kondisi. Hubungan kekerabatan seperti ini mengajarkan masyarakat Toba, Angkola dan Mandailing menjadi pribadi yang demokratis serta terbuka terhadap masyarakat luas.

Ketiga elemen pembentuk Dalihan na tolu didasari oleh sistem kekerabatan patrilineal. Artinya garis keturunan mengikuti marga dari bapak. Marga (clan) berfungsi untuk menentukan hubungan kekerabatan. Dengan marga seseorang dapat memastikan bagaimana pertalian kekerabatan atau sistem panggilan dengan orang lain (Gultom, 2010 : 50). Hubungan antar manusia dalam kehidupan orang Toba diatur dalam sistem kekerabatan Daliban na tolu. Hubungan berdasar sistim kekerabatan ini 
telah disosialisasikan kepada anak sejak dia mulai mengenal lingkungannya yang paling dekat dalam kehidupannya terutama ibu, ayah dan sudara-saudaranya. Bersamaan dengan perkenalan orang-orang lain itu diperkenankan kepadanya marga dan nilai yang terkandung di dalam pengertian marga lengkap dengan kode etik Daliban na tolu. Diperkenalkan pula kepadanya silsilah keluarga batih, bula-bula, boru dan marga Batak pada umumnya. Termasuk dalam proses sosialisasi awal inilah perkenalan tutur, panggilan kekerabatan lengkap dengan kata-kata kunci yang terdapat dalam perbendaharaan hubungan kekerabatan berdasar Daliban Na Tolu (Harahap \& Siahaan, $1987: 143)$.

Kekerabatan yang terikat dalam Dalihan na tolu baik dalam arti sempit maupun dalam arti luas, merupakan nilai utama pertama pada orang Angkola dan Mandiling. Kekerabatan yang disosialisasikan kepada anak-anak mencakup etika, sopan santun kekerabatan yang meliputi hubungan kekerabatan yang ada berdasarkan hubungan darah dan kekrabatan luas yang tercipta karena hubungan perkawinan. Semua hubungan kekerabatan itu dijalin dalam tutur yang jumlahnya banyak. Tutur bukan hanya sekedar istilah, kata, yang dipakai untuk menyapa orang lain, tetapi juga merupakan kata-kata kunci kekerabatan. Kata kunci itu menentukan posisi setiap orang dalam jaringan kekerabatan Dalihan $\mathrm{Na}$ Tolu. Ini menghasilkan orang AngkolaMandiling yang mudah menyesuaikan diri dengan lingkungan baru (Harahap \& Siahaan, $1987: 187)$.

Isilah kekerabatan orang Angkola-Mandailing berjumlah 38 tutur, yaitu: amang, inang, anak, boru, angkang, anggi, iboto, amangtua, namboru (inang boru), inangtua, uda, inang uda, amang boru, ompung, angkang mulak, tulang, nantulang (inang tulang), tunggane, eda, lae, bayo, anak namboru, boru tulang, boru tulang alalango, tulang alalango, ompung bayo, ompung dongan, bujing, nantulang alalango, amang na poso, tulang na poso, nantulag mulak, kahanggi, mora, anak boru, pisang raut, mora ni mora. Istilah kekerabatan yang banyak itu merupakan jalur penghubung yang menguatkan ikatan kekerabatan orang AngkolaMandailing (Harahap \& Siahaan, 1987 : 187).

Dalam pergaulan sehari-hari orang Angkola-Mandailing memiliki tiga gaya bicara yang khas sebagai cirri khas pula bagi wilayah tempat tinggalnya. Orang Mandailing dikenal pantis, berbicara lemah lembut dengan lantunan lagu kalimat yang merdu membujuk. Mereka bicara bergaya diplomatis, kadang-kadang tidak langsung pada pokok masalah. Mungkin ini disebabkan lembah Mandailing yang subur, banyak 
ditumbuhi pohon, sehingga tidak perlu bersuara keras. Orang Angkola bergaya bicara yang dikenal dengan laok, cepat akrab dengan menggunakan tutur kekerabatan, terus terang dan cepat lebur dalam citra kebersamaan. Karena pengaruh lingkungan yang lebih terbuka, bergunung-gunung dan berangin, dalam berbicara volume suara orang Angkola lebih besar dan meletup-letup dibanding volume suara orang Mandailing yang lebih kecil dan berirama. Gaya bicara ketiga ialah pupur yang dimiliki orang Padang Bolak, wilayah ini berada di dataran tinggi, bergunung, berangin dan padang steppe yang luas. Volume suara mereka lebih besar lagi disbanding volume suara orang Angkola, mereka bicara lebih lantang, tegas dan terbuka (Harahap \& Siahaan, $1987: 197-199)$.

\section{$>$ Kepercayaan Masyarakat}

Menurut Durkheim, solidaritas mekanik didasarkan pada suatu "kesadaran kolektif' bersama (collective consciousness/conscience), yang menunjuk pada "totalitas" kepercayaan-kepercayaan dan sentimen-sentimen bersama yang rata-rata ada pada warga masyarakat yang sama itu. Itu merupakan suatu solidaitas yang tergantung pada individu-individu yang memiliki sifat-sifat yang sama dan menganut kepercayaan dan pola normatif yang sama pula. Karena itu individualitas tidak berkembang, individualitas terus menerus dilumpuhkan oleh tekanan yang besar sekali untuk konformitas (Johnson, 1994 : 183).

Masyarakat bukanlah sekedar wadah untuk terwujudnya integrasi sosial yang akan mendukung solidaritas sosial, melainkan juga pangkal dari kesadaran kolektif dan sasaran utama dari perbuatan moral. Ciri khas solidaritas sosial mekanik adalah bahwa solidaritas itu didasarkan pada suatu tingkat homogenitas yang tinggi dalam kepercayaan, sentimen, dan sebagainya (Johnson, 1964 : 183).

Religi mencakup kehidupan keagamaan, baik agama tradisional maupun agama yang datang kemudian yang mengatur hubungannya dengan Maha Pencipta serta hubungannya dengan manusia dan lingkungan hidupnya. Kedudukan religi dalam nilai budaya Batak Toba sangat tinggi. Religi dalam pengertian ini adalah agama purba, atau agama asli orang Toba. Religi yang memasuki segala aspek kehidupan orang Toba tetap terpelihara, sekalipun banyak pengaruh memasuki kehodupan orang Toba seperti agama Kristen dan modernisasi. Semua pengaruh itu tidak pernah berhasil menghapus identitas orang Toba yang mempertahankan identitas kebatakannya (Harahap \& Siahaan, 1987 : 151). Walaupun masyarakat Batak 
Toba kini telah beragama, namun perilaku religinya tetap masih marak diwarnai oleh kepercayaan tradisional salah satunya menghormati nenek moyang, dapat dilihat dari banyaknya tugu nenek moyang yang berdiri, mulai daerah Siantar, Simalungun, hingga ke daerah Tapanuli, hingga ke daerah perantauan seperti Asahan dan Labuhan Batu.

Orang Angkola-Mandailing adalah masyarakat yang religus. Sekalipun adat istiadat tradisional dipelihara, namun aturan agama Islam sangat dominan dalam mengatur tata kehidupan sosial-budaya orang Angkola-Mandailing. Agama tradisional tergeser oleh ajaran agama Islam. Sehingga kehidupan religi orang Angkola-Mandiling secara keseluruhan diwarnai oleh agama Islam (Harahap \& Siahaan, 1987 : 187).

Faktor utama adat dan Islam bisa berdampingan lebih disebabkan oleh kekerabatan Daliban na tolu. Konsep sistem kekerabatan Dalihan na tolu secara fungsional memang menyatakan untuk melakukan adaptasi, mempunyai tujuan yang jelas dari mufakat, memelihara pola hidup dan mempertahankan kesatuan. Dengan ungkapan yang lebih tegas disebutkan bahwa bangunan dan simbol-simbol adat tetap hidup dan dipertahankan, akan tetapi muatannya sudah diganti oleh nilai dan ajaran Islam (Pulungan, 2003 : 300).

Pengaruh Islam yang kuat dalam kehidupan sosial budaya orang AngkolaMandailing jelas sekali dalam perkawinan. Dalam hal pemilihan jodoh misalnya ada perbedaan yang tegas antara aturan adat dengan aturan yang terdapat dalam ajaran Islam. Kawin semarga dilarang keras oleh adat, tetapi Islam membenarkannya. Dalam kenyataan sehari-hari telah banyak orang Tapanuli Selatan yang kawin semarga. Perkawinan semarga tidak lagi dipandang sebagai perbuatan terkutuk. Demikian juga pada upcara kematian yang dahulu banyak didominasi oleh upacara religi tradisional misalnya pemakaman yang diselenggarakan menurut tata cara adat, kini jarang terjadi (Harahap \& Siahaan, 1987 : 204).

\section{$>$ Keturunan dan Panjang Umur}

Hagabeon artinya banyak keturunan dan panjang umur. Sumberdaya manusia bagi orang Batak Toba, Angkola dan Manailing sangat penting, karena kekuatan yang tangguh hanya dapat dibangun dengan jumlah manusia yang banyak. Mengenai umur panjang dalam konsep hagabeon disebut saur matua bulung (seperti daun yang gugur sesudah tua) pada orang Toba. Religi dan hagabeon berkaitan erat sekali, karena kehormatan dan kemuliaan itu berhasil diraih hanya dengan berkat Debata Mulajadi 
$\mathrm{Na}$ Bolon yang dalam alam kenyataan didelegasikan kepada bula-bula. Mengenai kedudukan bula-bula, ungkapan tradisional menyebutkan bahwa bula-bula adalah Tuhan yang Nampak (bula-bula $i$ do Debata na niida). Permohonan hagabeon disampaikan bula-bula kepada Tuhan agar boru agar boru dapat gabe maranak sampulu pitu, marboru sampulu onom (jadi beranak laki-laki tujuh belas dan anak perempuan enam belas). Ukuran hagabeon adalah keluarga yang besar dan lanjut usia sekaligus menjadi tokoh panutan dalam masyarakat.

Orang Angkola-Mandailing memandang kebahagiaan hidup terkait erat dengan umur panjang, wibawa dan keturunan yang banyak. Sepanjang apa umur yang diidam-idamkan, sayur matur bulung lopus marsege-seger abuan, yakni seperti daun yang gugur setelah tua, sampai usia mencapai puncak sebagai orangtua terus berperangai kembali seperti anak kecil, menampi-nampi abu bermain bersama anak-anak kecil. Begitu besarnya idaman umur panjang itu, tetapi umur panjang saja dirasakan belum lengkap, oleh karena itu diharapkan agar seseorang sampai menuntun cucu. Itupun belum lengkap, kaena satu idaman terakhir ingin dicapai, ialah manyampebon rukun yang berarti menunaikan rukun Islam yang kelima, melaksanakan ibadah haji ke tanah suci Mekah. Anak tiga puluh tiga, itulah idaman keluarga besar menurut cita-cita tradisional Angkola-Mandailing (Harahap \& Siahaan, 1987 : 208).

\section{Kekayaan}

Hamoraon artinya kaya raya, merupakan salah satu nilai budaya yang mendasari dan mendorong orang Batak Toba, untuk mencari harta benda yang banyak. Dalam kehidupan sehari-hari hamoraon merupakan missi budaya yang menonjol. Perilaku ekonominya telah menjadi perhatian ahli-ahli antropologi dan sosiologi. Melihat hebatnya semangat orang Toba berjuang dan bekerja keras untuk mencapai hamoraon melalui keterlibatannya dalam bidang niaga, orang mengaitkan perilaku ekonomi orang Toba dengan teori Max Weber tantang hubungan etika Kristen dengan perilaku ekonomi pemeluknya.

Nilai budaya hamoraon dalam arti kekayaan bagi orang Angkola-Mandailing terkait erat dengan ajaran Islam, bahwa harta adalah titipan Allah untuk dimanfaatkan bagi kesejahteraan sendiri, kesejahteraan orang lain dan untuk dibelanjakan di jalan Allah. Membelanjakan harta di jalan Allah artinya memanfaatkan harta untuk kebahagiaan di dunia dan keselamatan di akhirat, salah satu cara yang ditempuh ialah dengan membayar zakat harta, berinfak dan bersedekah (ZIS = Zakat, Infak, 
Sedekah). Bila seorang Angkola-Mandiling beruntung menjadi orang yang kaya, dalam kehidupannya senantiasa berupaya untuk membagi harta itu secara ikhlas dan diam-diam sebagai amal jariah semata-mata karena mengharap ridha Allah SWTT (Harahap \& Siahaan, $1987: 220$ ).

Perihal kekayaan harta benda bukanlah merupakan tujuan utama hidup orang Angkola-Mandailing. Harta benda adalah merupakan buah perjuangan hidup, yang dapat dinikmati oleh bukan saja oleh pemiliknya, tetapai juga anggota kerabat bahkan siapa saja yang memerlukannya, misalnya anak yatim, dan fakir miskin dan sumbangan bagi pendirian sarana dakwah Islam, antara lain mendirikan rumah ibadah. Dibandingkan dengan orang Toba, semangat orang Angkola-Mandiling untuk menumpuk kekayaan sangat rendah (Harahap \& Siahaan, 1987 : 187).

\section{$>$ Pencapaian Kemuliaan}

Hasangapon artinya kemuliaan, kewibawaan, kharisma, suatu nilai utama yang memberi dorongan kuat untuk meraih kejayaan. Nilai ini memberi dorongan kuat pada orang Batak Toba pada zaman modern ini untuk meraih jabatan dan pangkat yang memberikan kemuliaan, kewibawaan, kharisma dan kekuasaan. Apabila seorang manusia Toba telah memiliki nilai kekerabatan, religi, hagabeon, kesadaran hukum, kemajuan, memiliki bisuk, kearifan dalam menyelesaikan berbagai konflik serta berjaya menjadi orang yang kaya, maka martabatnya sudah sampai pada taraf terhormat dan mulia. Inilah hasangapon, itu pula sebabnya hasangapon berada di tempat terakhir dari missi budaya hamoraon, hagabeon, hasangapon. Hasangapon boleh dikatakan merupakan hasil yang diperoleh setelah memiliki kejayaan dalam missi budaya bagabeon dan hamoraon. Hasangapon adalah hasil puncak dari missi budaya bamoraon, bagabeon, hasangapon itu (Harahap \& Siahaan, 1987 : 183).

Perbaikan mutu hidup dalam arti yang luas mencakup hasangapon yaitu kemuliaan dan kehormatan bagi orang Angkola-Mandailing terwujud dalam kedudukan yang baik, sebagai tokoh panutan yang diteladani. Orang AngkolaMandailing berpendapat bahwa hasangapon dapat diraih apabila nilai budaya kekerabatan, religi, hagabeon dan hamajuon telah dimiliki. Boleh dikatakan hasangapon adalah buah empat nilai utama tersebut diatas. Oleh karena itu perjuangan meraih hasangapon bukan merupakan perjuangan utama. Kemuliaan dalam keyakinan religius orang Angkola-Mandailing, hanya ada pada Tuhan, pada Allah SWT. Oleh karena itu, manusia hanya memperoleh kehormatan sebagai bagian hasangapon yang dapat 
diperoleh dengan memiliki akhlak mulia pula, jadi basangapon berakar pada hal-hal yang spiritual (Harahap \& Siahaan, 1987 : 216).

\section{Solidaritas Organik dalam Nilai Budaya Batak Toba, Angkola dan Mandailing}

Solidaritas organik muncul karena pembagian kerja bertambah besar. Solidaritas itu didasarkan pada tingkat saling ketergantungan yang tinggi. Saling ketergantungan itu bertambah sebagai hasil dari bertambahnya spesialisasi dan pembagian pekerjaan yang memungkinkan dan juga menggairahkan bertambahnya perbedaan dikalangan individu (Johnson, 1994 : 183).

\section{$>$ Kemajuan}

Hamajuon artinya kemajuan, diraih melalui merantau dan menuntut ilmu. Nilai budaya hamajuon sangat kuat mendorong orang Batak Toba untuk bermigrasi ke seluruh pelosok tanah air. Gerakan misi Kristen yang memasuki wilayah budaya Toba dan kehadiran penjajah di wilayah Tapanuli telah membawa perubahan yang mendasar terhadap peningkatan taraf hidup orang Toba. Gagasan pembaharuan yang dibawa oleh misionaris telah membuka cakrawala yang luas dalam wawasan orang Toba. Konsep hamajuon terbukti mendapat sambutan yang baik di kalangan masyarakat Batak Toba. Modernisasi yang diperkenalkan oleh orang kulit putih pada orang Toba mendorong gerak migrasi penduduk Tapanuli menuju pusat-pusat kemajuan di Sumatera Timur.

Hamajuon merupakan suatu upaya pengingkatan mutu masyarakat AngkolaMandailing yang dipelopori oleh Willem Iskandar di Mandailing dan gerakan missi Kristen oleh Rheinische Missionsgesellschaft (RMG) di Angkola-Sipirok, dengan mendirikan sekolah formal pada pertengahan abad yang lalu. Kehadiran sekolah di Angkola-Mandiling telah membuka cakrawala yang luas dalam upaya orang AngkolaMandailing meningkatkan mutu kehidupannya. Sejak itu gerakan migrasi orang Angkola-Mandailing ke berbagai tempat seperti Sumatera Timur, semenanjung Melayu dan pulau Jawa bukan lagi didorang oleh konflik di kampung halaman. Tetapi juga oleh semangat kemajuan yang dikumandangkan oleh Willem Iskandar melalui Kweekschool Tanobato yang didirikannya pada tahun 1862 di Mandailing dan sekolah-sekolah yang dikelola oleh orang-orang missi pada periode yang bersamaan 
di wilayah Angkola-Sipirok. Selain itu daya tarik tempat-tempat tujuan memang sangat kuat seperti pembukaan perkebunan di Sumatera Timur dan kesempatan kerja yang luas di Deli serta zaman keemasan pertambangan timah di Semenanjung (Harahap \& Siahaan, $1987: 211)$.

\section{Sitem Hukum}

Perkembangan masyarakat tidak mungkin bisa dilepaskan dengan perkembangan hukum, begitu pula sebaliknya. Dalam perkembangannya, masyarakat mengalami fase-fase atau tahapan-tahapan sebagaimana dikemukakan Durkheim dalam tulisan Evolution of Society and Social Solidarity (Milovanovic 1994 : 24). Dijelaskan perkembangan masyarakat dari solidaritas mekanik yakni dari masyarakat sederhana dan bersifat serba kolektif berkembang menjadi solidaritas organik yakni masyarakat modern dan komplek dengan segala pembagian kerja yang luas serta berkembang menjadi masyarakat individualistik.

Kesadaran hukum tradisional mengandung makna religi sedangkan kesadaran hukum formal mengandul makna hubungan antar manusia. Hukum tradisional adalah aturan yang dating dari Debata Mulajadi Na Bolon melalui nenek moyang bula-bula, yang mengatur kehidupan manusia dengan manusia dan alam sekitarnya, sekaligus mengatur hubungan manusia dengan roh nenek moyang dan Debata Mulajadi $\mathrm{Na}$ Bolon. Sedangkan hukum formal hanya mengatur hubungan manusia dengan manusia (Harahap \& Siahaan 1987 : 165). Hukum, patik dohot uhum (aturan dan hukum). Budaya menegakkan kebenaran, berkecimpung dalam dunia hukum, merupakan dunia orang Batak. Nilai ini mungkin lahir dari tingginya frekuensi pelanggaran hak asasi dalam perjalanan hidup orang Batak sejak zaman purba, sehingga mereka mahir dalam berbicara dan berjuang memperjuangkan hak-hak azasi. Masyarakat Batak Toba sangat banyak memberi poda (nasihat) yang menunjukkan jalan keluar bagi suatu masalah. Poda mencakup hal-hal yang berkaitan dengan sopan santun, etika sesuai dengan teladan yang diajarkan oleh nenek moyang.

Menurut pandangan orang Angkola-Mandailing, kadar kesadaran hukum seseorang dinilai dari ketaatannya pada padan (ikrar), hatigoran, adat dohot ugari, pantun serta patik dohot uhum. Dalam nilai udaya Batak pada umumnya, padan mempunyai kekuatan nilai religi. Pengingkaran padan dipercayai akan mengakibatkan kutukan. Padan dalam arti yang luas termasuk padan yang telah dilakukan oleh leluhur yang 
tidak boleh dilanggar oleh keturunannya. Peraturan dan undang-undang termasuk dalam kelompok patik dohot ubum kurang mengandung nilai religi (Harahap \& Siahaan, $1987: 221)$.

\section{Konflik}

Konflik dalam kehidupan orang Toba lebih tinggi kadarnya dibandingkan dengan yang ada pada orang Angkola-Mandiling. Ini dapat dipahami dari perbedaan mentalitas keduanya. Sumber konflik terutama dalam kehidupan kekerabatan dalam kehidupan orang Angkola-Mandailing, sedangkan pada orang Toba lebih luas lagi karena menyangkut perjuangan meraih hasil nilai budaya lainnya. Konflik dalam kehidupan orang Toba mengacu kemandirian dan dinamika sekaligus melatih orang Toba. Akar konflik terutama terletak pada nilai budaya hamoraon, hagabeon, hasangapon. Dimana perjuangan meraih hamoraon, hagabeon, hasangapon merupakan perjuangan sepanjang masa. Ketegaran dalam perjuangan hidup orang Toba diperkuat oleh hadirnya tantagan baru yang keras. Tantangan baru dihadapi dengan gihi dan berencana tanpa menyerah. Dalam keadaan semacam itu frekuensi konflik cenderung untuk meningkat. Agresivitas dan konflik mengandung nilai positif, karena bermuatan unsur-unsur penggerak kemajuan (Harahap \& Siahaan, 1987 : 165).

Cara yang paling aman menyelesaikan konflik pada orang AngkolaMandailing adalah mendiamkan konflik kecil. Sementara itu pihak yang terlibat konflik lambat laun menjadi rukun, karena frekuensi keterlibatan mereka dalam aktifitas kekerabatam terus berlangsung. Penyelesaian secara alamiah seperti ini biasanya lebih cocok untuk konflik kecil. Semakin besar konflik, semakin banyak pula anggota kerabat yang ambil bagian untuk mengakhirinya. Dalam keadaan yang pelik, kadang-kadang mora sebagai yang arif dan bijaksana, yang kata-katanya tidak boleh ditentang, terpaksa ditindak. Dalam keadaan demikian, tindakan arbitrase ini harus diterima oleh pihak-pihak yang terlibat konflik (Harahap \& Siahaan, 1987 : 228).

\section{Penganyoman}

Pengayoman dalam kehidupan sosio-kultural orang Batak kurang kuat dibandingkan dengan nilai-nilai yang disebutkan terdahulu. Ini mungkin disebabkan kemandirian yang berkadar tinggi. Kehadiran penganyom, pelindung, pemberi kesejahteraan, hanya diperlukan dalam keadaan yang sangat mendesak. Pengayom 
adalah pemberi kearifan, pemberi kesejahteraan, pelindung yang ditaati, pencipta ketentraman batin yang dalam sistem kekerabatan Dalihan na tolu diperankan oleh bula-bula. Kemandirian yang telah mendarah daging pada orang Toba, menempatkan kedudukan pengayom menjadi sangat terhormat. Pengayom hanya diperlukan pada saat-saat yang kritis, misalnya ketika yang diayomi mengalami penderitaan baik lahir maupun batin (Harahap \& Siahaan, 1987 : 185).

Mora atau raja dengan putera dan puterinya dalam kehidupan adat istiadat Angkola-Mandailing memegang peranan penting untuk menciptakan kesejahteraan dan ketenteraman. Posisi ini identik dengan penguasa dan seluruh aparatnya. Ini merupakan isyarat bagi pejabat yang bertugas di daerah untuk berperan sebagai mora, bukan sebagai kahanggi. Kahanggi adalah kawan sekaligus lawan bersaing dalam segala bidang kehidupan. Sebaliknya, tidak ada orang yang berupaya menyaingi mora, dalam konteks kehidupan kemasyarakatan berdasarkan Dalihan na tolu, apalagi menentangnya. Mora dijuluki mata ni ari so gakgahon, matahari yang tidak dapat dipelototi. Tetapi meskipun sangat menonjol kekuatan mora, namun apabila mora tidak lagi bertindak sebagai panutan, penganyom dan pemberi kesejahteraan karena melanggar norma yang berlaku baginya, maka yang diayomi cenderung untuk manjae. Manjae dalam kasus seperti ini, dapat diartikan sebagai suatu pembangkangan, silent resistance, yang seringkali dalam kenyataan hidup sehari-hari terwujud berupa pengambilan jarak, menjauh dan masa bodoh, apatis (Harahap \& Siahaan, 1987 : 224).

\section{Potret Interaksi dan Solidaritas Sosial Antar Umat Beragama di Tapanuli Utara}

Sejumlah ikatan sosial bersifat primordial mekanik seperti kekerabatan, kesukuan, dan komutitas. Ikatan ikatan ini jelas tidak dapat mempersatukan semua anggota suatu masyarakat yang komplek, tetapi merupakan sumber-sumber penting untuk solidaritas kelompok-kelompok inti yang tidak terbilang jumlahnya yang dapat mempersatukan masyarakat seluruhnya (Johnson, 1994 : 186).

Dalam pembinaan kerukunan hidup keluarga Batak Toba, Angkola dan Mandiling disosialisasikan rasa holong (kasih sayang) baik antara sesama orangtua, orangtua kepada anak dan anak kepada orangtua. Begitu pula antara bula-bula kepada boru dan boru kepada bula-hula. Dalam lagu-lagu masyarakat Batak Toba, Angkola- 
Mandiling, pesan bolong yang disampaikan terlihat dalam syair lagu, seperti; manortor ma bula-bula $i$ tahe, lao mamasu-masu boru na i, manortor manang boru na i tahe, lao manomba bulap-bula na $i$ (menari lah bula-bula itu, untuk memberkati boru nya itu, menari juga borunya itu, untuk menyembah bula-bulanya itu).

Solidaritas marga yang sangat kuat pada masyarakat Toba, Angkola dan Mandiling sudah dikenal secara luas. Walaupun tradisi mendidikan kampung tidak ada lagi sebagai awal kelahiran marga, solidaritas marga dan antar marga di luar kampung halaman tetap kuat. Daerah perantauan atau tempat tinggal yang baru merupakan kampung yang baru. Kecamatan Tarutung, Kecamatan Siborongborong dan Kecamatan Sipoholon secara perlahan telah menjadi kota yang beragam penduduknya serta menjadi tempat perantauan yang diminati masyarakat Toba, Angkola dan Mandiling. Pada tiga Kecamatan ini masyarakat Toba, Angkola dan Mandiling telah banyak mendirikan punguan (kumpulan), seperti kumpulan marga Siregar anak, boru, bere, ibebere dan perkumpulan kampung halaman (bonapasogit, bonabulub), seperti parsadaan sipirok na soli. Dengan demikian sistem kekebaratan Daliban na tolu tetap dapat dipertahankan. Keakraban kekerabatan diperantauan terus dipelihara dalam berbagai kesempatan dan pertemuan. Dengan demikian setiap anggota dari perkumpulan saling mengenal, sehingga apabila ada anggota kumpulan yang mengalami kesulitan hidup, anggota yang lain dapat membantunya, lebih lanjut konsep kumpulan saat ini telah mengarah kepada sistem Serikat Tolong Menolong (STM).

Kerjasama yang terjadi antar umat beragama di Tapanuli Utara dilaksanakan sebagian besar masyarakat Batak Toba, Angkola dan Mandailing. Kerjasama tersebut berlangsung dalam bentuk gotong royong dan tolong menolong. Kerjasama dalam bentuk gotong royong dilaksanakan melalui program-program gotong-royong yang digalakkan oleh Pemerintah baik pemerintah Kabupaten maupun Pemerintah di Kecamatan serta Forum Kerukunan Umat Beragama (FKUB). Gotong royong berupa pembersihan sarana dan prasarana umum seperti pembersihan jalan, ataupun pembangunan rumah Ibadah seperti Gereja dan Mesjid. Kegiatan gotong royong juga digalakkan oleh Serikat Kampung (Sarikat Huta). Serikat Kampung menjadi penggerak warga yang berbeda agama untuk saling tolong-menolong dalam setiap kegiatan suka maupun duka di suatu daerah. Dalam mempersiapkan konsumsi untuk acara pesta perkawinan maupun kematian, anggota masyarakat yang beragama 
Kristen menyembelih dan memasak hewan seperti babi, lembu, kerbau sedangkan anggota masyarakat yang beragama Islam mempersiapkan hewan sembelihan yang halal seperti ayam, kambing, dan bumbu masak. Begitu pula pada saat acara pesta berlangsung, anggota masyarakat yang beragama Kristen melayani konsumsi undangan yang beragama Kristen sedangkan anggota masyarakat yang beragama Islam melayani konsumsi makanan nasional (parsubang) atau undangan yang beragama Islam.

Interaksi sosial antar umat beragama di Tapanuli Utara dalam berbagai bentuk merupakan fakta sosial sebagaimana yang diutarakan oleh Durkheim. Interaksi antar umat beragama di beberapa daerah dalam bentuk akomodasi mulai memprihatinkan. Situasi ini terlihat pada beberapa daerah yang sudah mulai padat jumlah penduduknya serta heterogen dalam etnis, agama dan mata pencaharian seperti di Kecamatan Tarutung dan Kecamatan Siborong-borong, dimana Kecamatan Tarutung merupakan ibukota Kabupaten Tapanuli Utara dan Kecamatan Siborong-borong merupakan daerah pengembangan Kota baru. Jumlah Penduduk yang paling besar di Kabupaten Tapanuli Utara adalah terdapat di Kecamatan Siborong-borong dan Kecamatan Tarutung dengan masing-masing jumlah penduduknya adalah 47.428 jiwa dan 42. 419 Jiwa (BPS Kabupaten Tapanuli Utara, 2018: 1). Jumlah penduduk terbanyak ada di Kecamatan Siborongborong, sebesar 15,81 persen dari total penduduk Kabupaten Tapanuli Utara, sedangkan penduduk paling sedikit ada di Kecamatan Purbatua, sebesar 2,57 persen dari total penduduk Kabupaten Tapanuli Utara (BPS Kabupaten Tapanuli Utara, 2019: 5).

Heterogenitas penduduk di Kabupaten Tapanuli Utara disebabkan adanya urbanisasi penduduk dari luar Tapanuli Utara ke ibukota maupun kota baru di Tapanuli Utara. Terjadinya urbanisasi tentu dapat berakibat pada silang-budaya (Cross cultural) melalui adaptasi, akulturasi, dan asimilasi budaya (Al Rasyidin, dkk 2009: 205). Dengan demikian terjadi pergeseran dan tercipta kearifan-kearifan baru yang bukan hanya mengatur hubungan individual, namun juga menawarkan banyak nilai dan norma mengenai hubungan dalam masyarakat. Sebagian besar anggota masyarakat memiliki keinginan untuk hidup bersama dengan damai, ditandai dengan adaptasi nilai dan norma serta adat istiadat masyarakat setempat di kawasan Tapanuli Utara dan berusaha meleburkan ketegangan antara umat Kristen dan Islam, namun fakta di lapangan, semakin hari hal tersebut hanya pada tataran para pimpinan, seperti 
pemerintah daerah dan tokoh-tokoh agama, serta pada tataran pemikiran dan perkataan. Diantara anggota masyarakat telah mulai timbul rasa saling mencurigai satu sama lain, sebagian anggota masyarakat telah memegang prinsip agama masingmasing dan tidak bergaul dengan anggota masyarakat lain yang berbeda agama. Kehadiran masyarakat pendatang yang secara khusus bertujuan untuk mencari nafkah menimbulkan kecurigaan bagi masyarakat lokal yang menjadi tantangan tersendiri bagi tindakan akomodasi interaksi bagi terciptanya kerukunan antar umat beragama.

Proses asimilasi telah terjadi di beberapa daerah seperti di Kecamatan Pahe Julu, Kecamatan Pahae Jae, Kecamatan Simangumban, Kecamatan Purbatua, dan Kecamatan Adiankoting. Penduduk daerah tersebut telah beragam yang merupakan masyarakat Batak Toba, Angkola dan Mandailing serta memiliki keberagaman Agama Kristen dan Islam. Asimilasi dapat dilihat dalam pelaksanaan adat istiadat, seperti dalam hal hewan sembelihan pada acara suka maupun duka, di beberapa daerah walaupun masyarakatnya mayoritas beragam Kristen namun karena ada kerabat yang beragama Islam, maka hewan sembelihan yang diambil pada pelaksanaan pesta adalah kambing, lembu atau kerbau. Begitu pula dalam hal memberikan ulos, pada dasarnya bagi masyarakat Batak-Toba yang memberikan ulos adalah bula-bula kepada boru, namun sering dijumpai pembauran pada pelaksanaan adat istiadat boru memberikan ulos kepada bula-bula seperti adat masyarakat Angkola-Mandailing, bahkan tergantung rombongan/unsur keluarga yang datang mau melaksanakan mangulosi model Batak Toba atau Angkola, Mandailing. Demikian pula pada acara suka terlebih duka, pada masyarakat Batak Toba, bula-bula memberikan ulos kepada subut (keluarga yang melaksanakan pesta), dan dongan tubu memberikan tumpak (uang) kepada subut, namun pada masyarakat Angkola-Mandailing bukan hanya dongan tubu, rombongan bula-bula ikut juga memberikan tumpak kepada subut pada saat rombongan bula-bula masuk beracara atau manortor, sistem pemberian tumpak model Angkola-Mandailing ini di beberapa daerah telah diadaptasi masyarakat Batak Toba yang memiliki kerabat Angkola, Madailing. Pelaksanaan adat istiadat ini beberapa daerah yang pendudukanya telah bercampur masyarakat Batak Toba, Angkola, Mandailing menjadi suatu hal yang menarik dan menunjukkan adanya asimilasi karena telah terciptanya interaksi sosial yang baik antara umat beragama yang diikat oleh kekerabaran Daliban na tolu. 


\section{Penutup}

Manusia dalam lingkungan sosial selalu hidup bersama dan berinteraksi satu sama lain, sehingga timbul rasa kebersamaan. Rasa kebersamaan yang dimiliki masyarakat ini menimbulkan perasaan kolektif. Perasaan kolektif yang merupakan akibat (resultant) dari kebersamaan, adalah hasil aksi dan reaksi diantara kesadaran individual. Setelah menganalisis berbagai perkembangan masyarakat Batak Toba, Angkola dan Mandiling, agak sulit untuk mengelompokkan masyarakat tersebut ke dalam salah satu golongan secara tegas, baik kelompok masyarakat simpel (masyarakat mekanis) atau masyarakat kompleks (masyarakat organis). Lebih tepat bila dikatakan bahwa masyarakat Batak Toba dan Angkola dan Mandailing berada dalam masa transisi di antara keduanya.

Interaksi sosial antar etnis dan antar umat beragama di Tapanuli Utara memperlihatkan masih adanya keharmonisan ditandai dengan adanya adaptasi, asamilasi dan akulturasi di tengah-tengah masyarakat. Sedangkan pada daerah perkotaan maupun kota baru sikap individualis dan eksklusivisme telah muncul secara perlahan. Interaksi sosial yang tercipta masih sebatas pada anggota masyarakat yang memiliki hubungan kekerabatan maupun kesamaan identitas. Secara perlahan muncul pula segregasi relasi dan interaksi antar identitas, terkhusus identitas keagamaan.

Dalam kaitan dengan pembahasan pada penelitian ini, dapat dilihat interaksi sosial antar etnis dan antar umat beragama di Tapanuli Utara cenderung bersifat semu karena fakta sosial memperlihatkan bahwa solidaritas yang terjalin pada masyarakat di Tapanuli Utara hanyalah Solidaritas Mekanik yang secara perlahan telah menjebak dalam agama masing-masing dan belum kepada solidaritas antar umat beragama.

Keharmonisan menjadi modal utama untuk menghapus secara perlahan interaksi sosial yang semu di kalangan masyarakat, sehingga berbagai kecurigaan, perbedaan pandangan, pertentangan yang berujung pada konflik dapat terhindar dari masyarakat. Sistem kekerabatan Dalihan Na Tolu, Orientasi Nilai Budaya Batak Toba, Angkola dan Mandailing serta adaptasi, asimilasi dan akulturasi kearifan lokal merupakan alat utama untuk membangun Interaksi dan Solidaritas Sosial di tengahtengah masyarakat. 


\section{Daftar Pustaka}

Al Rasyidin , dkk. (2009). Penyerapan Nilai-Nilai Budaya Lokal Dalam Kebidupan Beragama Di Medan (Studi Tentang Budaya Lokal Di Medan), Harmonisasi Agama Dan Budaya Di Indonesia, Jakarta: Balai Penelitian Dan Pengembangan Agama Jakarta.

Ahmadi, Abu. (2007). Psikologi social. Jakarta: Rineka Cipta.

BPS Kabupaten Tapanuli Utara. (2018). Statistik Penduduk dan Ketenagakerjaan Kabupaten Tapanuli Utara 2018. Tarutung : Badan Pusat Statistik Tapanuli Utara.

BPS Kabupaten Tapanuli Utara. (2019). Statistik Daerah Kabupaten Tapanuli Utara 2019. Tarutung : Badan Pusat Statistik Tapanuli Utara.

Durkheim, Emile. (1964). The Divisoin of Labor in Society, trans.by George Simpson. New York: Free Press.

Milovanovic, Dragan. (1994). A Primer In The Sociology Of Law, Second Edition. New York: Harrow and Heston Publisher.

Gultom, Ibrahim. (2010). Agama Malim di Tanah Batak. Jakarta: Bumi Aksara.

Gultom, Rajamarpodang, Dj. (1992). Dalihan Na Tolu: Nilai Budaya Batak. Medan: Armanda.

Johnson, D. Paul. (1964). Teori Sosiologi Klasik dan Modern, Jilid I dan II, terj. Robert M.Z. Lawang, Jakarta: Gramedia.

Johnson, Doyle Paul. (1994). Teori Sosiologi Klasik Dan Modern. Jakarta: Gramedia Pustaka.

Jones, Pip. (2009). Pengantar Teori-Teori Sosial. Jakarta: Yayasan Obor Indonesia.

Harap, Basyral Hamidi dan M. Siahaan, Hotman. (1987). Orientasi Nilai-Nilai Budaya Batak Toba dan Angkola-Mandailing. Jakarta: Sanggar Willem Iskandar.

Meiyenti, Sri. dalam Robin Fox. (2012). Perubahan Istilah Kekerabatan Dan Hubungannya Dengan Sistem Kekerabatan Pada Masyarakat Minangkabau, Diakses dari www.Portalgaruda.Org Jurnal Antropologi, FISIF Universitas Andalas.

Pulungan, Abbas. (2003). Peranan Daliban Na Tolu Dalam Proses Interaksi Antara NilaiNilai Adat Dengan Islam Pada Masyarakat Mandailing Dan Angkola Tapanuli Selatan. Disertasi Diterbitkan Program Pascasarjana IAIN Sunan Kalijaga. 
Orientasi Nilai Budaya Batak Toba, Angkola Dan Mandailing Dalam Membina Interaksi Dan Solidaritas Sosial Antar Umat Beragama Di Tapanuli Utara (Analisis Sosiologis)

Riyanto, Armada CM. (2013). Menjadi-Mencintai. Yogyakarta: Kanisius.

Simanjuntak, Bungaran Anthonius. (2002). Konflik Status dan Kekuasaan Orang Batak Toba. Yogyakarta: Jendela.

Sinaga, Richard. (2006). Adat Budaya Daliban Na Tolu di Mata Alkitab dan Teologi Daliban Na Tolu. Jakarta: Dian Utama.

Soekanto, Soerjono. (1982). Teori Sosiologi Tentang Pribadi dalam Masyarakat. Jakarta: Ghalia Indonesia. 